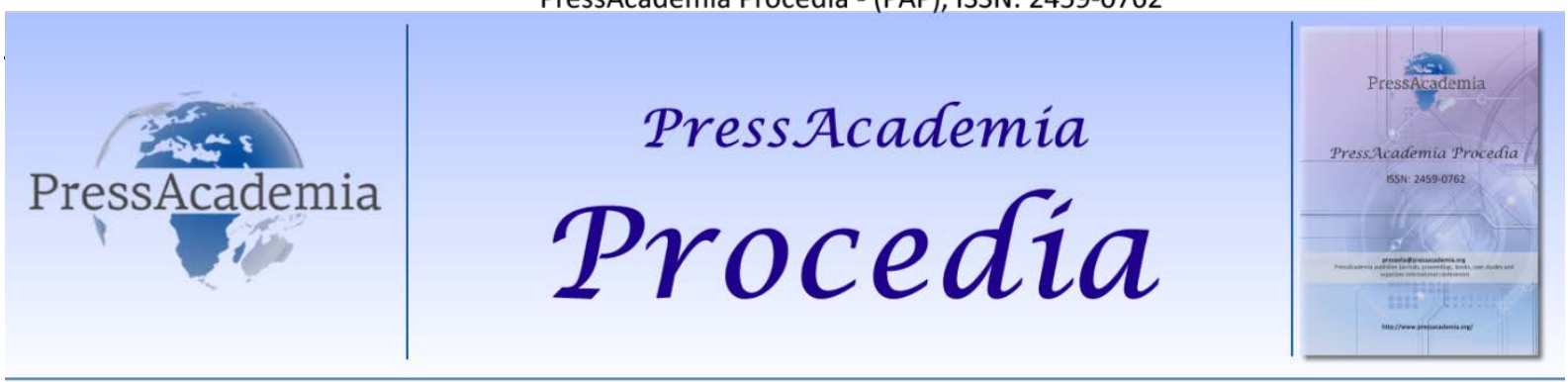

Global Business Research Congress (GBRC), May 26-27, 2016, Istanbul, Turkey.

\title{
EFFECTS OF GAP YEAR ON CAREER TRANSITIONS: A QUALITATIVE STUDY
}

\section{DOI: 10.17261/Pressacademia.2016118631}

\author{
Nihat Erdogmus ${ }^{1}$, Dogus Mirzanlı ${ }^{2}$ \\ ${ }^{1}$ Yıldız Teknik Üniversitesi. nihaterd@yildiz.edu.tr \\ ${ }^{2}$ Yıldız Teknik Üniversitesi. dogusmirzanli@outlook.com
}

\begin{abstract}
It is asserted that gap year activities have positive contributions, such as analyzing the current situation, evaluating potential transition scenarios, and gaining new abilities that facilitate career transition, to the qualified workforce that decided to change their career paths due to job related dissatisfaction with a sound and accurate implementations. In this study, volunteers that took a break to their professional lifes and worked abroad for Non Profit Organisations due to personal or professional dissatisfaction while working in the area that was related to their academic education were examined. Also reasons of gap year, causes and incentives of career transition, benefits acquired in the gap year and career transition after the process were investigated. Sample group was selected from the professionals that joined the European Volunteer Service projects 4 to 12 months. In data collection process semi structured interviews were held with the sample group of 17 people who are selected in accordance with the predetermined criteria. The results showed that gap year has positive contibutions on career transitions.
\end{abstract}

Keywords: Gap year, volunteering, non-profit organisations, career transition.

JEL Codes: J24, L30

\section{KARIYER GEÇIŞLERINDE BOŞLUK YILIN ETKISINi INCELEYEN NITEL BİR ARAŞTIRMA}

\section{ÖZET}

Kariyerlerinin erken evrelerindeki nitelikli işgücünün, mesleki tatminsizlikleri dolayısıyla verdiği kariyer geçiş kararlarının sağlıklı bir şekilde ve doğru yönde uygulamaya geçirilmesi noktasında; boşluk yıl faaliyetlerinin, bireylere, mevcut durumu analiz etme, potansiyel geçiş senaryolarını değerlendirme, kariyer geçişini kolaylaştırıı yeni yetenekler kazanma gibi pozitif katkılar sağladığı ifade edilmektedir. Bildiride; önlisans veya lisans eğitiminin ardından, akademik eğitimini aldığı alanda çalışmaya başlayan fakat daha sonrasında kişisel ve mesleki tatminsizlikler dolayısıyla profesyonel yaşamlarına ara verip, yurtdışında kar amacı gütmeyen organizasyonlarda gönüllü olarak çalışan bireylerin, bu süreç içerisindeki kazanımları ve profesyonel yaşama dönüşleri incelenmektedir. Çalışmada boşluk yılın sebepleri, kariyer geçişinin güdüleyicileri, boşluk yıl sürecindeki kazanımlar ve süreç sonunda yapılan kariyer geçişi incelenmektedir. Bildiride örneklem Avrupa Gönüllü Hizmeti kapsamında 4 ile 12 ay arasında çalışan profesyonellerden oluşmaktadır. Veri toplama sürecinde belirlenen kriterler çerçevesinde oluşturulan 17 kişilik örneklem grubuyla yarı yapılandııılmış mülakatlar gerçekleştirilmiştir. Araştırma sonucunda boşluk yılın kariyer geçiş sürecine olumlu katkı sağladığı bulgusu elde edilmiștir.

Anahtar Kelimeler : Boşluk yıl, gönüllülük, kar amacı gütmeyen kuruluşlar, kariyer geçişi.

JEL Kodları: J24, L30. 


\section{GiRiş}

2. Dünya savaşı sonrası; makro bağlamda bir barış ve refah döneminin içerisine girilmesiyle birlikte, ortalama yaşam süreleri geçmişte olmadığı kadar yükseklere çıkmıştır. Küresel bağlamda oluşan ekonomik büyüme, yaşam standartlarını yükseltmiş; eğitimin genele yayılması, şehirleşme ve demokratik yönetim eğilimlerinin yaygınlaşması gibi sonuçlara yol açmıştır (Simpson, 2004, 36).

Refah toplumlarında, doğurganlık oranlarının yaşam süreleriyle ters orantılı olarak düşüş gösterdiği ve genç nüfusun toplam nüfus içerisindeki oranının gittikçe azaldığı görülmektedir. Dolayısıyla piyasaya giren yeni işgücü sayısı zaman içerisinde miktarsal olarak azalma eğilimi gösterirken, bireylerin istihdam piyasasında kalma, yani kariyer, süreleri artmaktadır. Örneğin; A.B.D. Çalışma İstatistikleri Bürosu ülkedeki potansiyel lider havuzunun (35-44 yaş işgücü) araştırmanın yapıldığı tarihten sonraki 10 sene içerisinde yüzde 15 oranında küçüleceği öngörüsünde bulunmuştur (Gandossy ve Guarnieri, 2008, 65).

Diğer taraftan ise iyi eğitim almış nitelikli genç popülasyonun toplam genç nüfus içindeki payı oransal olarak artmaktadır. Bu durumla doğru orantılı olarak da nitelikli işgücü, toplam işgücü pastasından daha yüksek bir pay almaya başlamaktadır (UNDP, 2014). 21. yüzyılda refahın daha geniş coğrafyalara taşınması, enformasyon ve teknoloji temelli global işletme modellerinin ön plana çıkması ve uzmanlaşmanın değer kazanmasıyla, nitelikli işgücünün pazardaki önemi artarken; her bir bireyden maksimum fayda sağlamak insan kaynakları uygulamalarının temel düşüncesi halini almıştır.

Bu yeni dönemde hızı gittikçe artan global göçler ve nüfus akışı, sınır ötesi değişimler ve yetişmiş insan kaynağının uluslararası hareketliliği; gelişmiş ülkelerdeki sosyal politikaların da evrilmesine, çeşitliliğin ve çok kültürlülüğün önem kazanmasına yol açmaktadır (Lyons vd., 2012, 361-362).

Öte yandan eğitimli, uluslararası topluma entegre, genç, çalışan popülasyonunun iş hayatındaki beklentileri de geçmiş dönemdeki muadillerine kıyasla farklılaşmaktadır. Kişisel hedeflerin öncelik kazandığı bu yeni dönem; örgüt içerisindeki görevlerine, pozisyonlarına ve hatta mesleklerine karşı memnuniyetsizlik yaşayan geniş bir işgören grubu meydana getirmiştir.

Tüm bu sebepler dolayısıyla, araştırma, nitelikli genç insan kaynağının beklenti, beceri ve maksimum potansiyelinin ortaya çıkarılması doğrultusunda; bireysel kariyer beklentileri karşılanamamış çalışanlara odaklanmaktadır. Bu kişilerin belli bir ara verme ve mevcut durumlarını gözden geçirme ihtiyaçları bulunmaktadır. Bu bağlamda araştırmanın ana problemi;

“Kariyer geçişlerinde boşluk yılın etkisi var mıdır?” olarak belirlenmiştir.

Çalışmanın ana amacı da; kariyerlerinin başlangıç dönemlerindeki genç işgörenlerin, iş yaşamındaki mesleki ve kişisel tatminsizlikleri sebebiyle, Avrupa Gönüllü Hizmeti aracılığıyla, profesyonel hayata kısa süreli bir ara vermeleri ve bu boşlukta çokuluslu bir çevrede yaşama, toplumsal fayda temelli faaliyetlerde bulunma, dil öğrenme vb. eylemleri sonrasında iş hayatına döndüklerinde, kariyerlerinde gerçekleştirdikleri değişimleri incelemektir.

\section{LITERATÜR TARAMASI}

Geleneksel insan sermayesi teorisi, hayatın ilk aşamalarında alınan bir akademik eğitim ve sonrasında çalışma yaşamında geçirilecek uzun bir kariyer süresini gerçek (normal) dünya döngüsü olarak adlandırmaktadır (Holmlund vd., 2006, 3). Bu döngü, günümüz toplumlarında kişilerin bitmek bilmeyen bir çabalama ve yarışma halinde bulunmalarına, çoğunlukla da ilk tercihleri olmayan durumların içerisine girmelerine neden olmaktadır. Bu sebeple de ruhen sağlıksız, tükenmişlik hissi yaşayan bireyler ve daha geniş bir ölçekte de sağlıksız toplumlar ortaya çıkmaktadır.

Türkiye özelinde ise; eğitim çağındaki bireylere ilgi ve yetenek bazlı analizler doğrultusunda kariyer rotaları belirlenememesi, aile yapılarının ve kültürel yapının dayatmaları gibi nedenlerle de; kişiler, yetişkinlik dönemlerinde arzu etmedikleri kariyer rolleri üstlenmek zorunda kalmaktadır. Çalışma yaşamı içerisindeki memnuniyetsiz insan grubu, sözü edilen eğitim/kariyer döngüsü içerisinde kısa bir süreliğine nefes alacak veya 
yaşamlarındaki düzen hakkında değerlendirme yapabilecek bir zaman dilimine sahip olamadan, belli belirsiz bir sıkışmışlık hissi içinde yaşamlarını sürdürmektedir.

Bu noktada, Boşluk Yıl; Kuzey Amerika, İngiltere, Kuzey Avrupa ve Avustralya gibi refah bölgeleri özelinde önemi vurgulanan, üzerine akademik araştırmalar yürütülen bir düşünce ve faaliyetler bütünüdür.

\subsection{Boşluk Yıl (Gap Year)}

Boşluk yıl kavramı; bireylerin akademik veya profesyonel hayatlarına vermiş oldukları, süresi 3 ay ile 24 ay arasında değişebilen, ara bir dönemi tanımlamaktadır (Qian, 2013, 16). Bir başka ifade ile boşluk yıl; bir kişinin eğitim veya iş hayatını askıya aldığı bir periyottur.

Kavramın İngilizce karşılığı olan "gap year" teriminin ilk olarak hangi zamanda literatüre girdiği kesin olarak bilinmemekle birlikte, zaman içerisinde, kapsamına çeşitli faaliyetlerin eklendiği ve sadece seyahat edilen bir zaman dilimini tanımlamaktan daha geniş bir anlam çerçevesine oturtulduğu görülmektedir (Simpson, 2004, 11). Başlangıçta mevcut yaşam rutinlerinin terkedilmesi ve konvansiyonel eğitim-kariyer sürecinin reddedilmesi olarak algılanan boşluk yıl düşüncesi, zaman içerisinde bu döngünün bir parçası olarak değerlendirilmeye başlanmıştır.

Konu; Türkçe literatürde bir akademik çalışma alanı olarak henüz kendisine yer bulamamış ve Türkçe'de kavramı tam olarak tanımlayan bir ifade ortaya konamamıştır. Bu nedenle de İngilizce'den birebir çeviri karşılı̆ı boşluk (gap) yıl (year), çalışmada kavramı tanımlamak için kullanılmıştır. Öte yandan ise Türkiye'deki eğitimli genç nüfus içerisinde de boşluk yıl faaliyetlerine katılan çok sayıda kişi bulunduğu görülmektedir. Çeşitli akademik ve mesleki sınavlara hazırlanma süreçleri, dil öğrenimi için yapılan yurtdışı planlamaları boşluk yıl uygulamalarına örnek olarak gösterilebilir.

Her ne kadar eğitim veya iş hayatına verilen bir ara, kişinin mevcutta var olan yükümlülüklerini bir kenara bırakması noktasında önemli bir fırsat olarak görülse de; boşluk yıl, belirli bilgi, beceri ve yeteneklerin kazanıldığı bir dönem olarak tanımlanmaktadır. Boşluk yıl kapsamında değerlendirilen faaliyetlere katılımın temel amaçları; bireyin kişisel ilgi ve beklentileri ile ilişkili zaman geçirmesi, diğer yandan da uzun vadede işgücü piyasasında rekabetçi avantajlar sağlayacak özellikler kazanması veya var olan özelliklerini güçlendirmesidir. Bu bakımdan profesyonel yaşam ile boşluk yılda geçirilen zaman diliminin içiçe geçmiş yaşam evreleri oldukları ifade edilebilir (Cremin, 2007, 526-528).

Bireysel beklentiler haricinde, uluslararası boşluk yıl faaliyetlerine katılımın sebepleri olarak; farklı ülkeler görmek, kişisel tecrübeleri arttırmak, kendi ülkesi hakkında yeni bir bakış açısı kazanmak, global bir vatandaş olarak küresel mirası keşfetmek, öğrenilmek istenilen bir dilin ana vatanında yaşamak, profesyonel ve finansal potansiyeli arttırmak, kendi kültürünü tanıtarak farklı coğrafyalarda oluşan önyargılı düşünceleri ortadan kaldırmak (Qian, 2013, 3) gibi beklentiler de bulunmaktadır.

Literatüre bakıldığında boşluk yılda yapılabilecek temel faaliyetler ana başlıklarıyla; uzun süreli ve özellikle kıtalararası seyahatlere gitme, yurtiçi veya yurtdışında kar amacı gütmeyen kurumlarda gönüllü projelerde yer alma, ücretli veya ücretsiz stajlara katılma, uzun vadeli bir planı gerçekleştirmek hedefli olarak belirli bir süre için ücret karşılığı çalışma, çeşitli akademik veya mesleki sınavlara tekrar hazırlanma, yurtiçi veya yurtdışı eğitim ve sertifika programlarına katılma, şeklindedir (Crawford ve Cribb, 2012, 28).

Yine, boşluk yıl ile kariyer gelişimi arasında pozitif yönlü bir ilişki olduğunu ifade eden çeşitli çalışmalara da literatür içerisinde rastlanmaktadır (Jones, 2004; Noy, 2004; Simpson, 2004; Holmlund vd., 2006; Cremin, 2007; Söderman ve Snead, 2008; Crawford vd., 2012; Qian, 2013). Bu çalışmalarda boşluk yıl süresince; zaman yönetimi, çok kültürlü bir yapıya entegre olabilme, dil öğrenimi, kariyer beklentilerini güncelleme veya var olanı pekiştirme gibi çok çeşitli becerilerin kazanılabileceği veya geliştirilebileceği ifade edilmektedir. Bu kazanımların da bireylere; kariyer değişimleri, gelişimleri ve geçişlerine giden yollar açtıkları ileri sürülmektedir.

\subsection{Kariyer Geçişi (Career Transition)}

21. yüzyılda iş yaşamının önemi ve bu dönem içerisindeki geçişler yüksek bir oranda artış göstermiştir. Super (1980), kişilerin bir kariyer gelişim döneminden bir başkasına geçerken, kariyer geçişleri yaşadıklarına vurgu 
yapmaktadır. Genel kabul görmüş tanımıyla kariyer geçişi (career transition); çalışanların bir kariyer durumundan başka bir kariyer durumuna geçtiği süreci ifade etmektedir.

Kariyer geçişi, farklı araştırmacılar tarafından, çeşitli şekillerde gerçekleştiği ileri sürülen bir olgudur. 20. yüzyılın ikinci yarısından itibaren, kariyer geçişi konusuyla ilişkili çok sayıda düşünce ve teorinin ortaya çıktığı görülmektedir.

Latack (1984), kariyer geçişini tanımlarken; organizasyon içi hiyerarşik seviye atlamaları (intraorganizational), organizasyonlar arası değişimler (interorganizational) ve meslekler arası değişimler (interprofessional) olmak üzere 3 farklı tip geçişten söz etmektedir.

Heppner ise; aynı işyeri veya bölgede gerçekleşen görev değişimi (task change), mevcut iş sorumluluklarını değiştiren hiyerarşik pozisyon değişimi (position change) ve meslek değişimi (occupation change) olmak üzere üç kariyer geçiş yolu olduğunu ileri sürmüştür (Heppner, 1998, 137).

Bir başka görüş de, kariyer geçişinin temelde; istemli/iradi (voluntary) veya istemsiz/irade dışı (involuntary) olarak iki ana başlıkta kategorize edilmesi gerektiğidir (Fouad ve Bynner, 2008). Bu görüşe göre; istemli kariyer geçişlerinde geçiş, bireysel tercihler ışığında ortaya çıkmakta; istemsiz kariyer geçişleri ise kişisel ve çevresel kısıtlar dolayısıyla oluşmaktadır.

Kariyer geçiş kavramıyla ilişkili araştırma ve tanımlamalara bakıldığında ise ilk olarak; Nancy Schlossberg'in 4S modeli karşımıza çıkmaktadır (Pendleton, 2007, 45). Schlossberg; insanların geçiş dönemindeki değişimleri anlamlandırabilmesi ve onlarla baş edebilmesini sağlayan; durum (situation), bireyin kendisi (self), destek (support) ve stratejiler (strategies) olmak üzere 4 temel faktör bulunduğunu ifade etmektedir. Bahsi geçen faktörlerin İngilizce karşılıklarının ilk harflerinden ötürü de modele, 4S modeli ismi verilmiştir (Schlossberg, 1981).

Nicholson da, iş değişimlerinin daha iyi anlaşılabilmesi amacıyla bir geçiş döngüsü modeli ortaya çıkarmıştır. Model, geçiş döngüsünün 4 aşamalı bir süreç içerisinde gerçekleştiğini ileri sürmektedir. Nicholson'ın modelinde yer alan aşamalar sırasıyla; hazırlık (preparation), yüzleşme (encounter), adaptasyon (adjustment) ve kararlılık (stabilisation) şeklindedir. Fakat adından anlaşılacağı üzere aşamalar birbirini takip eden bir döngü biçiminde süreklilik arz etmektedir (Nicholson, 1987; Harris vd., 2012).

Sonrasında Bridges da bir kariyer geçiş modeli üzerinde çalışmış ve yeni bir durumun ve bu durumdan dolayı ortaya çıkan değişimlerin farkedildiği, sonrasında da kabul edildiği geçiş sürecinin bitiş (ending), nötr/tarafsız bölge (neutral zone), yeni başlangıç (new beginning) olmak üzere 3 aşamalı gerçekleştiğini ileri sürmüştür (Bridges, 1991).

2000'li yıllarda ise Ibarra tarafından yapılmış araştırmalar ve örnek olay çalışmaları bulunmaktadır. Yürüttüğü detaylı çalışmalarda çeşitli mesleki dallara mensup bireylerin kariyer geçiş süreçlerini inceleyen araştırmacı, kariyer değişimi için; yeni profesyonel aktiviteler denemek, yeni sosyal ağlarla ilişki içine girmek, kim olduğumuzla alakalı olarak kendimize ve başkalarına anlattığımız hikayeye yenilikler katmak olmak üzere 3 bölümlü bir süreç tanımlamaktadır. Ibarra; çok kapsamlı bir ön planlama, analiz ve anlamlandırma çabası yerine; küçük adımlarla, kişinin kendisine uyan çevre, görev ve rol tanımlamalarına ulaşmasına vurgu yapan stratejilerden söz etmektedir (Ibarra, 2003).

Temel olarak geçiş süreci; çalışanların bir olay, durum veya fikir aracılığıyla farkındalık kazanmasından ya da belirli ihtiyaçların eksikliğinden dolayı başlayabilmektedir. Bireylerin harekete geçme/geçmeme kararlarını vermelerine neden olan bu tetikleyiciler ya da eksiklikler, devamlı tekrar eden bir öz değerlendirme veya mevcut durum değerlendirme eylemlerinin sonucunda ortaya çıkmaktadır (Mihal vd., 1984: 97). Ibarra'ya göre; tetikleyiciler ve eksiklikler direk olarak bir değişim meydana getirmemekte; bunun yerine kişilerin bireysel tercihleri doğrultusunda, alternatif seçenekler keşfetme ihtiyacını ortaya çıkarmaktadır (Ibarra, 2003).

Mevcudiyetleriyle ya da eksiklikleriyle, kişilerin kariyer geçiş sürecine girmelerine neden olabilecek güdüleyiciler olarak; kariyer motivasyonu, iş-kişilik uyumu, kültür, bireysel kariyer yönetimi, kariyer çıpaları, sosyal paylaşım ağları, iş ve aile çatışması, yaş veya jenerasyon kavramları ön plana çıkmaktadır (London, 1983; Chudzikowski vd., 2009; Schein, 1984; Schein, 1996, 80; van Rensburg, 2014, 126; Robbins, 2001). 


\section{VERI VE YÖNTEM}

Çalışmada, nitel araştırma tekniklerinden mülakat yöntemi kullanılmıştır. Sosyal Bilimler alanında, uzun zamandan beri kullanılan mülakat (interview) tekniği, tüm farklı formlarıyla önemli bir veri toplama aracı olma özelliğini korumaktadır (Yıldırım ve Şimşek, 2005). Verilerin elde edilmesi temel olarak, yarı yapılandırılmış etkileşimli mülakatlar ve katılımcı gözlemleri aracılığıyla sağlanmıştır.

Çalışmanın örneklem grubu; Avrupa Gönüllü Hizmeti (AGH) kapsamında projeler üreten, Avrupa merkezli sivil toplum kurumları ve yerel kuruluşlar için uzun dönemli gönüllülük faaliyetlerine katılmış kişilerden oluşmaktadır. Gönüllülük, boşluk yıl faaliyet türlerinden bir tanesidir. AGH; T.C. Avrupa Birliği Bakanlığı AB Eğitim ve Gençlik Programları Merkezi Başkanlığı tarafından şu şekilde tanımlanmaktadır:

"Bir sivil toplum kuruluşu ve yerel topluluk için sosyal içerikli projelerde çalışmalarda bulunma. Öncelikle ve en önemlisi, gönüllü olarak çalışırken yaptığınız iş için maaş benzeri bir ücret almazsınız. Bununla birlikte yiyecek, barınma, dil eğitimi, yerel ulaşım, sigorta, bireysel bakım ve yardım ve az miktarda cep harçlığı alabileceksiniz. Bir AGH projesi, kısa süreli (2-8 hafta - sadece engellilere ve imkanları kısıtlı gençlere yönelik) ya da uzun süreli (2-12 ay) olarak bir AB ülkesinde gönüllü olmanıza imkan tanımaktadır."

Katılımcılar; 286 kişilik bir aday grubu içerisinden, incelenecek değişkenlerle alakalı taşımaları beklenen temel özellikler çerçevesinde seçilmişlerdir. Bu özellikler;

o Avrupa Gönüllü Hizmeti projelerine katılım öncesi minimum, önlisans veya lisans düzeyinde bir eğitim programını bitirmiş olmak,

o Önlisans/lisans eğitimi sonrası, Avrupa Gönüllü Hizmeti projelerine katılım öncesinde, eğitimi alınan akademik bölümle alakalı minimum 1 işte görev almak,

o Kariyeriyle alakalı; mesleki ve kişisel sebeplerden ötürü memnuniyetsizlikler yaşamak. Bu nedenle de boşluk yıla ihtiyaç duymak,

o Minimum 4 ay - maksimum 12 ay süre zarfında, Türkiye dışında gerçekleşen bir Avrupa Gönüllü Hizmeti projesinde gönüllü olarak yer almak,

o Gönüllülük faaliyeti sonrası, mezun olunan önlisans/lisans bölümüyle uyumu aranmaksızın, minimum 1 işte çalışmak, şeklindedir.

Illk etapta belirlenen potansiyel adaylara, yukarıdaki temel özelliklerle uyumlarını görmek hedefiyle, çalışmaya uygunluk formu gönderilmiştir. Gelen cevaplar sonucunda yapılan ön elemenin ardından uygun görülen 32 adayın bulunduğu ikinci bir grup belirlenmiştir. Mülakatlar da, müsait durumda olan ve görüşmeye katılım isteği belirten 17 kişi ile gerçekleştirilmiştir. Katılımcılardan 5 tanesi yurtdışında, 2 tanesi de Türkiye içinde İstanbul dışında bir şehirde yaşamlarını sürdürdüğünden; bu katılımcılarla yapılan görüşmeler internet üzerinden, görüntülü ve sesli iletişim kaynakları yoluyla gerçekleştirilmiştir.

Görüşmeler; katılımcıların somut ve etkinlik bazlı bilgilerini, aynı zamanda da konu hakkındaki soyut düşüncelerini keşfetme odaklıdır. Mülakatın biçimsel gidişatı belirlenirken çalışma kapsamında hangi bilgilerin edinilmesi gerektiği değerlendirilmiş ve soruların 8 ana başlığa ayrılması uygun bulunmuştur. Bu ana başlıklar;

o Çalışma grubunun genel yapısını öğrenmeye yönelik sorular,

o Kariyer geçiş süreci öncesi genel görünümün belirlendiği sorular

o Gönüllü olarak çalışma tercihinin çıkış noktalarının belirlendiği sorular,

o Avrupa Gönüllü Hizmeti tercihi ve proje seçim aşaması ile ilgili sorular,

o Avrupa Gönüllü Hizmeti projesinde geçirilen süre ile ilgili sorular

o Gönüllü çalışma sonrası kariyer durumlarını belirlemeye yönelik sorular,

o Mevcut kariyer durumlarını belirlemeye yönelik sorular

o Başlangıcından bitişine tüm geçiş sürecinin genel değerlendirmesi ile ilgili sorular, şeklindedir.

\section{BULGULAR VE TARTIŞMA}

Boşluk yıl faaliyetlerinin kariyer geçiş sürecine etkilerini incelemeye yönelik olarak yürütülen mülakat çalışmalarından elde edilen temel bulgulardan ve ilerleyen dönemde yapılacak akademik çalışmalarda üzerinde durulabilecek ana noktalardan aşağıda söz edilmiştir. 


\subsection{Bulgular}

Gerçekleştirilen mülakatlar sonrasında; boşluk yıl ihtiyacının sebepleri, kariyer geçişinin güdüleyicileri, boşluk yıl faaliyetinin kariyer geliştirici kazanımları, kariyer geçişinin mevcudiyeti ve alt türleri konularında çeşitli bilgilere ulaşılmıştır.

\subsubsection{Boşluk Yıl ihtiyacının Sebepleri}

Görüşmelere katılan kişilere, boşluk yıl ihtiyacının ana sebeplerini belirlemek üzere;

"Hangi sebep veya sebeplerle çalışma yaşamınıza bir ara verme ihtiyacı hissettiniz? Sizi rutinin dışına iten düşünceler nelerdi?" sorusu yöneltilmiştir.

Boşluk yıl rutin düzenin kırıldığı bir ara olarak görülse de uzun dönemli kariyer beklentileri için üretken bir dönem olarak değerlendirilmektedir. Yukarıdaki sorunun amacı da, kişilerin verilen aranın süresini normal eğitim-kariyer döngüsü içerisinde, farklı bir örgüt yapısına girerek de değerlendirebilme seçeneğine rağmen neden boşluk yıl faaliyetini tercih ettiğini belirlemektir.

Katılımcılar; iş yaşamının temposu içerisinde, özellikle kariyer geçişine yol açacak memnuniyetsizlikler yaşadıkları bir süreçte, kendilerine zaman ayıramamaktan ve bu nedenle de geçişe olanak sağlayacak yeterlilikleri kazanamamaktan dolayı böyle bir tercihte bulunduklarına vurgu yapmışlardır. Kendi yaşam alanına dışarıdan bir göz olarak bakabilme fikri de mevcutta var olandan uzaklaşma isteğini perçinlemektedir.

Örneğin katılımcılardan bir tanesi boşluk yıl faaliyetine katılma gerekçelerini sıralarken; “ileriye dönük neler yapabilirim, hangi alanlarda yeteneğim var, daha çok aslında kendimi tanıma kendimi keşfetme gibi nedenlerle, bilinçaltımda bu amaçla bu arayı vermeyi kabul etmiştim" açıklamasında bulunmuştur.

Faaliyetlere Avrupa kıtası özelinde katılım sağlama isteğinin arkasında ise; coğrafi yakınlık ve Batı medeniyetiyle alakalı pozitif tarihsel algıların yattığı görülmektedir. Katılımcılar, sosyal fayda temelli bir gönüllülük projesinde yer almakla ve bu durumdan manevi tatmin sağlamakla birlikte; Avrupa iş piyasasını gözlemleme ve çok uluslu bir ortamda bulunma özellikleri dolayısıyla faaliyetleri kariyer geliştirici bir unsur olarak tanımlamaktadır.

Yine katılımcıların çoğunluk görüşü olarak; bu aranın bireysel tercihler ışığında hissedilen sıkışmışlık duygusunu bertaraf edebilmek adına yapıldığı söylenmektedir.

\subsubsection{Kariyer Geçişinin Güdüleyicileri}

İşgörenlere, kariyer geçiş düşüncesinin ortaya çıkış durumunun tetikleyicileri olarak hangi sebepleri ön plana çıkardıklarına dair;

"Akademik eğitimini aldığınız bölüm ile ilgili beklentileriniz, çalışma yaşamına girmeden önce ve ilk iş tecrübe(ler)iniz esnasında var olan kariyer hedefleriniz nelerdi?" ve

"Hangi sebep veya sebeplerle mevcut çalışma yaşamınızdan ve kariyer yolculuğunuzdan memnun değildiniz? Değişim ihtiyacı ne şekilde ortaya çıktı?”, şeklinde iki temel soru yöneltilmiştir.

Heppner'ın (1998) kariyer geçiş sınıflaması içerisinde tanımladığı meslek geçişini gerçekleştiren katılımcıların, çoğunluk görüşü olarak, akademik eğitimini aldıkları alanla alakalı iş-kişilik uyumunu sağlayamadıkları ve bu uyumsuzluğu, geçişi başlatan ana etmen olarak gördükleri görülmektedir. Pozisyon değişimi gerçekleştiren katılımcılarda ise, en önemli problem olarak; işletme ve örgütsel yapıdaki sorunlar ile ilerleme ihtiyaçları dolayısıyla kariyer motivasyonu sağlayamamaları ön plana çıkmaktadır. Bununla birlikte geçiş sürecini gerçekleştiren tüm bireylerin kariyer esnekliklerinin ve kariyer sezgilerinin yüksek olduğu gözlemlenmiştir.

Katılımcıların ortak görüşü olarak; yaşanılan ülkenin, toplumun ve bu sınırlar içerisindeki örgütlerin kültürel yapısı, geçiş sürecini zorlaştıran ve bireyleri değişim riskinden alıkoyan etmenlerden bir tanesidir. Bu noktada değişim ihtiyaçlarını karşılamaya yönelik adımlar atan işgörenlerin, bilişsel beceri, kişisel farkındalık, duygusal esneklik ve kişisel yönlendirme gibi bireysel kariyer yönetimi bileşenlerine sahip oldukları görülmektedir. Bireysel olarak amaçladıkları değişim haricinde, kişilerin var olan mevcut toplumsal kalıpları da zorlama eğiliminde oldukları bu nedenle de geçiş öncesi değil, geçiş kararını verdikten sonra aile ve sosyal paylaşım 
ağlarından destek görme arzusu taşıdıkları fakat bu desteği görmeseler dahi değiş̧imi gerçekleştirmek için adımlar attıkları gözlemlenmiştir.

Kariyer geçiş düşüncesinin ortaya çıkmasını tetikleyen bir diğer güdüleyici olarak ifade edilen kariyer çıpası kavramının; teknik/fonksiyonel yeterlilik, girişimci yaratıcılık, amaca hizmet etme ve kendini adama, meydan okuma, yaşam stili (Schein, 1996, 80) gibi alt bileşenlerinin de katılımcılar tarafından vurgulanan temel düşüncelerle ve yaşadıkları geçişlerle yakından ilişkili olduğu belirlenmiştir.

\subsubsection{Avrupa Gönüllü Hizmeti Faaliyetinden Elde Edilen Kazanımlar}

Gönüllülük ve çalışma özelinde Avrupa Gönüllü Hizmeti projeleri, katılımcılarının çeşitli kazanımlar elde etmelerine olanak sağlamaktadır. Temel hedefi Avrupa Birliği içerisinde kültürel kaynaşmayı/entegrasyonu ve sosyal yardımlaşmayı güçlendirmek olan AGH'den sağlanan bireysel faydalar ise katılımcılar tarafından şu şekilde dile getirilmiştir.

Kariyer beklentileri içerisinde, uluslararası bir firmada hatta ülke sınırları dışarısında çalışmak olan mülakat cevaplayıcılarının, yabancı dil bariyerlerinin aşıımasında ve bu sayede mesleki anlamda kendilerini geliştirecek ortamı yaratmalarında, katılıkları projelerin ciddi bir katkısı olmuştur. Yabancı dil, özellikle de İngilizce, becerilerinin gelişmesi istisnasız tüm katıımcıların ifade ettiği bir kazanım olarak karşımıza çıkmaktadır. Bununla birlikte temel iletişim becerilerinin gelişimine vurgu yapan çok sayıda kişi de bulunmaktadır.

Boşluk yıl faaliyeti; birçok katılımcı için yurtdışında ilk yaşam tecrübesi olduğundan, kişisel olgunlaşma, zaman ve bütçe yönetimleri noktalarında da bireylere artı değer katmıştı. Benzer şekilde çeşitliliğin ve kültürel etkileşimin yoğun olduğu proje ortamı dolayısıyla, katılımcıların küresel birer vatandaş olarak insanlığın kültürel mirasının farkına varma durumuna geçtikleri gözlemlenmiştir. Çok kültürlü yapının içerisinde farkı ülkelerden insanlarla bir araya gelerek arkadaşlık ilişkileri kurmanın da, ulusal sınırlardan dolayı oluşan basmakalıp düşünceleri yok ettiği görülmüştür. Bu noktada katılımcılardan bir tanesi;

"Millet kavramı ortadan kalktı benim için, global bir insan oldum. Herkesi kendi karakteri üzerinden değerlendirmeye başladım." ifadesiyle önyargılarından kurtulma durumunu ortaya koymuştur.

Proje sonrası iş arama sürecinde, yukarıda sözü edilen çok kültürlü bir ortamda yaşama ve dünya vatandaşlığı düşüncesini içselleştirme özelliği dolayısıyla katılımcılar, yurtdışı merkezli örgütler ve yurtiçindeki uluslararası firmalar üzerinde pozitif bir algı oluşturmuşlar ve talep görmüşlerdir. Birçoğu, bahsi geçen firmalarda kariyerlerini sürdürmektedir.

Proje süresince katılımcılar, yaşamlarına ve kariyerlerine dönük bir öz değerleme sürecine de girmişlerdir. Kendi tercihleri, güçlü ve zayıf yönleri, ilgi alanları ve yönelebilecekleri mesleki dallarla alakalı derinlemesine analizler yürütmüşlerdir. Rutin eğitim-kariyer çizgisi içerisinde insanların sahip olamadıkları istisnai bir zaman dilimi yaratmayı başaran kişiler, bu sayede standart kalıpların dışarısına çıkabilmiş ve yaşamlarına dışardan bir göz olarak bakabilmişlerdir.

\subsubsection{Kariyer Geçişi Alt Türü}

Araştırma kapsamında görüşme yapılan kişilerin tamamı; belirli temel kriterleri taşıyan, kariyer geçiş sürecini yaşayan ve geçiş sonucunda profesyonel yaşamlarında değişimler olan kişilerdir. Kariyer geçişi alt türleri belirlenirken Heppner (1998) ve Latack (1984) tarafından yapılmış sınıflamalar ve tanımlamalar göz önünde bulundurulmuştur. Heppner'ın; görev, pozisyon ve meslek geçişleri ile Latack'ın organizasyon içi, organizasyonlar arası ve meslekler arası geçişleri birçok noktada benzer kriterleri taşımakla birlikte bazı farklılıkları da içinde barındırmaktadır.

Katılımcıların mezun oldukları akademik departman, bu departmanla ilişkili yürüttükleri ilk iş tecrübeleri ve geçiş sonrası mevcutta var olan kariyerleri ve iş tanımları neticesinde ne tür bir kariyer geçişi yaptıkları ile alakalı olarak,

"Şu anda hangi meslek dalında görev alıyorsunuz. Mevcut durumda sahip olduğunuz işten kısaca söz eder misiniz?" ve 
"Gönüllülük faaliyeti öncesi kariyer durumunuz, beklentileriniz ile şu andaki kariyer durumunuz kıyaslandığında neler söylersiniz? Ne tür değişimler, farklılıklar yaşandığını düşünüyorsunuz?”, soruları sorulmuştur.

Elde edilen bilgiler ışığında da katılımcıların gerçekleştirdiği kariyer geçişlerinin alt türleri belirlenmiştir.

Tablo 1: Kariyer Geçişi Alt Türü

\begin{tabular}{|c|c|c|c|c|c|}
\hline Katılımcı & $\begin{array}{l}\text { Mezun Olduğu } \\
\text { Bölüm }\end{array}$ & İlk İş Tecrübesi ve Mesleği & Kariyer Geçişi & $\begin{array}{l}\text { Geçiş Alt } \\
\text { Türü } \\
\text { (Heppner) }\end{array}$ & $\begin{array}{l}\text { Geçiş Alt Türü } \\
\text { (Lattack) }\end{array}$ \\
\hline Katılımcı 1 & $\begin{array}{l}\text { Türk Dili ve Edebiyatı } \\
\text { Lisans }\end{array}$ & Edebiyat Öğretmenliği & Akademiye Dönüş & Meslek & Meslekler Arası \\
\hline Katılımcı 2 & $\begin{array}{c}\text { Uluslararası Lojistik } \\
\text { Önlisans/İşletme } \\
\text { Lisans }\end{array}$ & Lojistik Elemanı/Uzmanı & Lojistik Uzmanı/Müdür Yardımcısı & Pozisyon & $\begin{array}{c}\text { Organizasyonlar } \\
\text { Arası }\end{array}$ \\
\hline Katılımcı 3 & Biyoloji Lisans & $\begin{array}{l}\text { Hastane Laboratuar } \\
\text { Elemanı/Asistanı }\end{array}$ & Satış Temsilcisi/Müşteri iliş̧kileri & Meslek & Meslekler Arası \\
\hline Katılımcı 4 & Sosyoloji Lisans & Felsefe Grubu Öğretmenliği & Sosyal İnceleme Görevlisi Sosyolog & Meslek & Meslekler Arası \\
\hline Katılımcı 5 & $\begin{array}{c}\text { Elektronik ve } \\
\text { Haberleşme } \\
\text { Mühendisliği Lisans }\end{array}$ & $\begin{array}{l}\text { Teknik Destek ve Satış Temsilcisi } \\
\text { (Mühendis) }\end{array}$ & İş Sağlığı ve Güvenliği Uzmanı & Meslek & Meslekler Arası \\
\hline Katılımcı 6 & $\begin{array}{l}\text { Turizm ve Otel } \\
\text { İşletmeciliği Önlisans }\end{array}$ & $\begin{array}{c}\text { Turizm Sektörü/Servis Elemanı- } \\
\text { Komi }\end{array}$ & $\begin{array}{l}\text { Turizm Sektörü/Demi Chef (Kıdemli } \\
\text { Şef)+ }\end{array}$ & Pozisyon & Organizasyon İçi \\
\hline Katılımcı 7 & $\begin{array}{c}\text { Bilgisayar } \\
\text { Programcılığı Önlisans }\end{array}$ & Yazılım Sektörü/İçerik Yöneticisi & $\begin{array}{c}\text { Elektronik Yazılım Sektörü/Teknik } \\
\text { Destek Uzmanı+ }\end{array}$ & Pozisyon & $\begin{array}{c}\text { Organizasyonlar } \\
\text { Arası }\end{array}$ \\
\hline Katılımcı 8 & $\begin{array}{l}\text { Endüstri Mühendisliği } \\
\text { Lisans }\end{array}$ & $\begin{array}{l}\text { Üretim Planlama ve Maliyet } \\
\text { Departmanı Uzmanı }\end{array}$ & $\begin{array}{c}\text { Bilgisayar Programcılığı ve Yazılım } \\
\text { Uzmanı+ }\end{array}$ & Meslek & Meslekler Arası \\
\hline Katılımcı 9 & İşletme Lisans & $\begin{array}{c}\text { Maliyet ve Hakediş Düzenlemesi } \\
\text { Elemanı }\end{array}$ & $\begin{array}{l}\text { Kozmetik ve Gıda Ürünleri } \\
\text { Departman Müdürü }\end{array}$ & Pozisyon & $\begin{array}{c}\text { Organizasyonlar } \\
\text { Arası }\end{array}$ \\
\hline Katılımcı 10 & $\begin{array}{l}\text { Turizm ve Otel } \\
\text { Iş̧letmeciliği Önlisans }\end{array}$ & $\begin{array}{l}\text { Turizm Sektörü/Otel Servis } \\
\text { Elemanı }\end{array}$ & Akademiye Dönüş/Fotoğrafçılık & Meslek & Meslekler Arası \\
\hline Katılımcı 11 & $\begin{array}{l}\text { Uluslararası Iliş̧iler } \\
\text { Lisans }\end{array}$ & $\begin{array}{l}\text { Uluslararası Firma Yurtdışı } \\
\text { illişkiler Elemanı }\end{array}$ & Muhasebe/Fatura Uzmanı & Meslek & Meslekler Arası \\
\hline Katılımcı 12 & $\begin{array}{c}\text { Grafik Tasarım } \\
\text { Önlisans/Sosyal } \\
\text { Bilimler Lisans }\end{array}$ & Tasarım Uzmanı & Tasarımcı/Konfigürasyon Uzmanı & Pozisyon & $\begin{array}{c}\text { Organizasyonlar } \\
\text { Arası }\end{array}$ \\
\hline Katılımcı 13 & Tarih Lisans & Sınıf Öğretmenliği & Bütçe ve Raporlama Uzmanı & Meslek & Meslekler Arası \\
\hline Katılımcı 14 & $\begin{array}{l}\text { Amerikan Kültürü ve } \\
\text { Edebiyatı Lisans }\end{array}$ & İngilizce-Türkçe Çevirmen & Üniversite İngilizce Okutman & Meslek & Meslekler Arası \\
\hline Katılımcı 15 & Arkeoloji Lisans & Uzman Arkeolog & Saha Fotoğrafçısı ve Kameraman & Meslek & Meslekler Arası \\
\hline Katılımcı 16 & $\begin{array}{l}\text { Çalışma Ekonomisi ve } \\
\text { Endüstri İlişkileri }\end{array}$ & $\begin{array}{l}\text { Insan Kaynakları } \\
\text { Elemanı/Uzmanı }\end{array}$ & İnsan Kaynakları Uzmanı/Yöneticisi & Pozisyon & $\begin{array}{c}\text { Organizasyonlar } \\
\text { Arası }\end{array}$ \\
\hline Katılımcı 17 & $\begin{array}{l}\text { Uluslararası iliş̧kiler } \\
\text { Lisans }\end{array}$ & $\begin{array}{c}\text { Uluslararası Firma Sigorta } \\
\text { Bölümü Elemanı }\end{array}$ & $\begin{array}{c}\text { Banka/Bireysel Müşteri Iliş̧kileri } \\
\text { Uzmanı }\end{array}$ & Meslek & Meslekler Arası \\
\hline
\end{tabular}


Heppner'ın kariyer geçiş alt türleri sınıflaması kapsamında değerlendirildiğinde; 6 kişinin pozisyon geçişi, 11 kişinin ise meslek geçişi yaptığı görülmüştür. Öte yandan görev değişimi yapan katılımcı ise bulunmamıştır.

Lattack'ın kariyer geçiş alt türleri sınıflaması kapsamında bir değerlendirme yapıldığında ise; 1 kişinin organizasyon içi geçiş, 5 kişinin organizasyonlar arası geçiş, 11 kişinin meslekler arası geçiş yaptıkları görülmüştür.

Bununla birlikte mevcut durumda sahip olduğu iş tanımından ve kariyerinin geldiği noktadan memnuniyet duyan kişi sayısının ise 13 kişi olduğu yapılan görüşmeler sonrası elde edilen bir bilgidir. 4 katılımcı ise şu an sahip oldukları işleri, çeşitli zorunluluklar ve kısıtlar nedeniyle devam ettirdiklerini ifade etmişlerdir.

\subsection{Tartışma}

Kişilerin var olan kariyer durumlarını değerlendirme ve kariyer geçişi sürecinin içerisine girmeleri noktasında boşluk yılın pozitif etkisi olduğunu ileri süren farklı çalışmalar bulunmaktadır. Örneğin Heath (2007), katılımcıların; etkili iletişim, organizasyonel takım çalışması becerileri gibi sosyal yetenek kazanımları sağladıklarını ileri sürmüştür. Konu hakkında pozitif değerlendirmeler yapan akademik çalışmaların odağında, boşluk yıl faaliyetlerinin; öğrenme, eğitim ve beceri gelişimi gibi konularda kişilere fayda sağladığı düşüncesi yer almaktadır. Faaliyet katılımcılarına istinaden belirtilen ufuklarını genişletme fikri de sözü edilen faydalarla bağdaşmaktadır.

Araştırma kapsamında, yürütülen mülakat çalışmaları neticesinde de katılımcıların, gerçekleştirdikleri kariyer geçişlerinde, katıldıkları boşluk yıl faaliyetinin önemine ve bu dönemdeki kazanımlarına vurgu yaptıkları gözlemlenmiştir.

Diğer tarafta ise, herhangi bir tecrübenin kaçınılmaz sonucunun öğrenme olduğu iddiasında bulunan ve bu nedenle boşluk yıl süresindeki kazanımların konudan bağımsız değerlendirilmesi gerektiğini savunan bir karşıt görüş de mevcuttur. Sözü edilen bu görüşün aksi yönünde de; kazanımların beklenmedik veya anormal şartlarda elde edilmesi ve biçimsel tecrübe kazanılamayan bu dönemde iş piyasasındaki rekabetçi avantajın yok olmasını engellemesi (Cremin, 2007, 538-539), boşluk yıl faaliyetinin diğer herhangi bir tecrübeye karşı üstünlüğü olarak ifade edilmiştir.

Kariyer geliştirici bir süreç olarak algılanan boşluk yıl faaliyetine katılmanın, gelecekte elde edilecek kazancı negatif yönde etkilediği yönünde araştırmalar da mevcuttur (Holmlund vd., 2006, 5). Bu araştırmaya göre; eğitim veya iş hayatından ayrılarak boşluk yıl faaliyetlerine katılan bireyler, 30 yaşına geldiklerinde faaliyetlere katılmayan muadillerine göre daha az para kazanmaktadır. Faaliyetlerin süresi uzadıkça bu maddi fark daha da artmaktadır. 2 yıl süren bir boşluk yıl faaliyetinin yaşattığı maddi kaybın bugünkü değerinin; 40 yaşında bir çalışanın yıllık gelirinin yaklaşık yüzde 50'si olduğu belirlenmiştir. Bu nedenle de boşluk yılda harcanacak kıymetli zamanın, iş piyasası içerisinde değerlendirilmesi gerekliliğine vurgu yapılmıştır.

\section{SONUÇ}

Kişiler; temel eğitimlerinin bitiminde veya üniversite-iş yaşamı içerisinde kariyerlerinin herhangi bir döneminde, rutin hayat akışının dışına çıkabilecekleri istisnai bir süreye intiyaç duyabilmektedir. Verilen araların temel hedefi, bireyin, kendisini yaşam evreleri arasındaki geçişlere hazırlamasıdır. Geçiş dönemlerindeki belirsizlik ortamını verilen aralarla yumuşatma denemelerinde bulunan insan sayısı artış gösterdikçe de toplumun kalıplaşmış, eğitim alma-çalışma üzerine kurulmuş, düşünce yapısından sıyrılarak daha esnek bir bakış açısına doğru yol almaya başladığı görülmektedir.

Özellikle temel eğitimden üniversite eğitimine geçiş sürecinde katılımcıları ne şekilde etkilediği konusunda yapılmış araştırmalar olmakla birlikte, boşluk yıl faaliyetlerinin farklı yaşam evreleri ve değişkenlerle etkileşimini inceleyen çalışmaların azlığı küresel ölçekte de görülmektedir. Kavramın, yürüyütülen araştırma özelinde değişkenlerden bir tanesi olarak seçilmesinin temel nedeni; Kuzey Amerika, İngiltere, Kuzey Avrupa ve Avustralya gibi, modern işletme ve yönetim bilimi düşüncelerinin geliştiği bölgelerde akademik çalışma alanı olarak algılanmasına rağmen, Türkçe literatürde konu hakkında herhangi bir öncül çalışmanın yapılmamasıdır. Türkiye'nin ekonomik ve kültürel anlamda bir dönüşüm sürecinin içinde olması, eğitimli genç nüfus oranının, kariyer beklentilerinin ve örgütsel yapıların yukarıda söz edilen refah bölgeleriyle benzerliklerinin artması, 
çokuluslu firmaların ulusal iş piyasasındaki etkileri, küresel vatandaşlık düşüncesinin ülkemizde de yaygınlaşması gibi nedenlerle bu araştırmanın; ilerleyen dönemde konunun Türkiye ölçeğinde de akademik öneminin artacağı öngörüsüne dayanarak, boşluk yıl kavramı hakkında bir kaynak rolü üstleneceği ümit edilmektedir.

Diğer yandan, kişisel veya mesleki memnuniyetsizlikler dolayısıyla kariyerlerinde bir değişim sürecine giren işgörenlerin yapmaya çalıştıkları kariyer geçişleri de, çalışmanın bir diğer değişkeni konumundadır. Kavram hakkında, önemiyle ters orantılı olarak, işletme, yönetim ve insan kaynakları alanlarında yapılmış akademik çalışmaların hem ülkemiz hem de dünya genelinde; liderlik modelleri/davranışları, örgütsel bağlılık/gelişim/tatmin/vatandaşlık gibi konularla kıyasladığında oldukça dar bir çerçevede kaldığı görülmektedir.

Yürütülen araştırma da bu kapsamda; "Boşluk yıl faaliyetlerinin kariyer geçişine etkisi var mıdır" sorusuna yanıt aramaktadır.

Gerçekleştirilen görüşmeler; boşluk yıl faaliyetlerinden biri olarak kabul edilen gönüllülük projelerine Avrupa Gönüllü Hizmeti $(A G H)$ özelinde katılan genç profesyonellerin edindikleri tecrübelerin, becerilerin ve toplamda elde ettikleri kazanımların kariyer geçişine ne derecede etkisi olduğuna odaklanmaktadır. Yapılan detaylı literatür taramaları ve mülakatlar sonrasında; boşluk yıl faaliyetlerinin, iş yaşamının ilk evrelerindeki profesyonellerin kariyer geçiş sürecine girmelerine ve süreç sonucunda farklı bir hiyerarşik pozisyonda veya meslek kolunda kariyerlerine devam etmelerine yardımcı etkileri olduğu sonucu elde edilmiştir. Katılımcıların, meslek geçişi yapma oranlarının daha yüksek olduğu ve çoğunluk görüşü olarak, gerçekleştirdikleri geçişe karşı pozitif bir algı içerisinde oldukları gözlemlenmiştir.

Görüşmelerin yapıldığı örneklem grubu, 1980-1990 yılları arasında doğan, Y kuşağı içerisinde değerlendirilen kişilerdir. Bahsi geçen Y kuşağı işgörenlerin, çalışma yaşamında çoğunluk grup olmaya başlamasıyla birlikte 21 . yüzyıl yönetim uygulamaları da bu grubun elemanlarının öncelikleri etrafında şekillenmeye başlamıştır. Bu kapsamda, Y kuşağı ve iş piyasasına yakın zamanda girmesi beklenen bir sonraki grup olan $Z$ kuşağı mensuplarının artan değişim ve esneklik talepleri hem boşluk yıl hem de kariyer geçişi kavramlarının yakın gelecekte öneminin daha da artacağı öngörüsüne yol açmaktadır.

\section{KAYNAKLAR}

Bridges, William. 1991. "Managing Transitions: Making the Most of Change”, Reading, MA: Addison-Wesley.

Chudzikowski, Katharina, Barbara Demel, Wolfgang Mayrhofer, Jon P. Briscoe, Julie Unite, Bilijana Bogicevic Milikic, Douglas Tim Hall, Mireia Lea Heras, Yan Shen, Jelena Zikic. 2009. "Career Transitions and Their Causes: A Country-Comparative Perspective", Journal of Occupational Psychology, vol. 82, pp. 825-849.

Crawford, Claire, Jonathan Cribb. 2012. "Gap Year Takers: Uptake, Trends and Long Term Outcomes”, Institute for Fiscal Studies Through the Centre for Analysis of Youth Transitions (CAYT). Research Report: DFE-RR252. United Kingdom.

Cremin, Colin. 2007. "Living and Really Living: The Gap Year and the Commodification of the Contingent", Ephemera: Theory and Politics in Organization Journal. vol. 7, no. 4, pp. 526-542.

Fouad, Nadya A., John Bynner. 2008. “Work Transitions”. American Psychologist, vol. 63, no. 4, pp. $241-251$.

Gandossy, Robert, Robin Guarnieri. 2008. “Can You Measure Leadership”. MIT Sloan Management Review. vol. 50, no.1, pp. 64-69.

Harris, Martin W., M, E. Myhill. J. H. Walker. 2012. "A Promising Career? The Thriving Transition Cycle”, International Journal of Sports Science, vol. 2, no. 3, pp. 16-23.

Heath, Sue. 2007. "Widening the Gap: Pre-University Gap Years and the Economy of Experience". British Journal of Sociology of Education. vol. 28 , no. 1 , pp. 89-103.

Heppner, Mary J. 1998. "The Career Transition Inventory: Measuring Internal Resources in Adulthood", Journal of Career Assessment. vol. 6, no. 2, pp. 135-145.

Holmlund, Bertil, Qian Liu, Oskar Nordström Skans. 2006. “Mind the Gap: Estimating the Effects of Postponing Higher Education”, IFAU Institute for Labour Market Policy Evaluation. Working Paper. pp. 2006:11. Sweden.

Ibarra, Herminia. 2003. "Working Identity: Unconventional Strategies for Reinventing Your Career", Harvard Business School Press. Boston. 
Jones, Andrew. 2004. "Review of Gap Year Provision”, Department for Education and Skills. Research Report RR555. London.

Latack, Janina C. 1984. "Career Transitions within Organizations: An Exploratory Study of Work, Nonwork, and Coping Strategies", Organizational Behavior and Human Performance. vol. 34, pp. 296-322.

London, Manuel. 1983. "Toward a Theory of Career Motivation”, Academy of Management Review, vol. 8, no. 4, pp. 620-630.

Lyons, Kevin, Joanne Hanley, Stephen Wearing, John Neil. 2012. “Gap Year Volunteer Tourism: Myths of Global Citizenship", Annals of Tourism Research. vol. 39, no. 1, pp. 361-378.

Mihal, William L., Patricia A. Sorce, Thomas E. Comte. 1984. "A Process Model of Individual Career Decision Making", The Academy of Management Review, vol. 9, no. 1, pp. 95-103.

Nicholson, Nigel. 1987. "The Transition Cycle: A Conceptual Framework for the Analysis of Change and Human Resource Management", Research in Personnel and Human Resources Management, vol. 5, ed. J. Ferris and Kendrith. M. Rowland. Greenwich, Connecticut: JAI Press.

Noy, Chaim. 2004. "This Trip Really Changed Me: Backpackers' Narratives of Selfchange”, Annals of Tourism Research. vol. 31, no. 1, pp. 78102 .

Pendleton, Kathy J. 2007. “Using Schlossberg's Transition Theory to Identify Coping Strategies of Welfare Recipients Attending Postsecondary Institutions", Phd Thesis, The University of Louisville.

Qian, Rui. 2013. "Benefits and Constraints of Gap Year". Master Thesis. Kent State University College and Graduate School of Education, Health, and Human Services.

Robbins, Stephen. 2001. “Organizational Behavior”, Upper Saddle River, New Jersey: Prentice Hall International.

Schein, Edgar H. 1984. "Culture as an Environmental Cotext for Careers", Journal of Occupational Behaviour, vol. 5, no. 1, pp. 71-81.

Schein, Edgar H. 1996. "Career Anchors Revisited: Implications for Career Development in the 21st Century", The Academy of Management Executive, vol. 10, no. 4, pp. 80-88.

Schlossberg, Nancy K. 1981. "A Model for Analyzing Human Adaptation to Transition”, The Counseling Psychologist, vol. 9, no. 2, pp. 2-18.

Simpson, Kate. 2004. "Broad Horizons? Geographies and Pedagogies of the Gap Year", Phd Thesis. Newcastle University Library.

Söderman, N., Suzanne Leigh Snead. “Opening the Gap: The Motivation of Gap Year Travellers to Volunteer in Latin America. Journeys of Discovery in Volunteer Tourism: International Case Study Perspectives", ed. Kevin Lyons, Stephen Wearing. Wallingford: CAB International. 2008: 118-129.

Super, Donald E. 1980. "A Life-Span, Life-Space Approach to Career Development”, Journal of Vocational Behavior. vol. 16, pp. $282-298$.

UNDP. “Sustaining Human Progress: Reducing Vulnerabilities and Building Resilience”. Human Development Report 2014.

http://www.undp.org/content/dam/turkey/docs/Publications/hdr/2014\%20Human\%20Development\%20Report\%20-\%20English.pdf [04.01.2016].

Van Rensburg, Adele Janse. 2014. "Evaluating the Career Transition Phenomenon", Phd Thesis. Faculty of Industrial Psychology and People Management, University of Johannesburg.

Yıldırım, A., Şimşek, H. 2008. "Sosyal Bilimlerde Nitel Araştırma Yöntemleri" 6. Baskı, Ankara: Seçkin Yayıncılık. 